\title{
Determinants of Investment Flows in U.S. Manufacturing
}

\author{
Jason P. Brown, ${ }^{*}$ Raymond J.G.M. Florax, and Kevin T. McNamara ${ }^{+}$
}

\begin{abstract}
The purpose of the paper is to test the long-run steady state of growth factors hypothesized to influence U.S. manufacturing investment flows. These factors include agglomeration, market structure, labor, infrastructure, and fiscal policy. Spatial cross-regressive and spatial Durbin models are used to measure the spatial interaction of investment flows. Spatial spillovers are found to be of a competitive nature at the state level, implying that a factor which attracts more investment to a particular state is associated with lower investments in neighboring states. Investment flows to states with higher market demand, more productive labor, and more localized agglomeration of manufacturing activity.
\end{abstract}

Key words: manufacturing; investment; spatial Durbin model

JEL Classifications: $L 6 ; R 11 ; R 30$

\section{INTRODUCTION}

Manufacturing employment in the U.S. has been on a steady, long-term decline since the 1960s. At the same time, real wages (with the exception of those in the late 1970s and early 1980s) and real investment on total capital and manufacturing output have been increasing. During this 40-year period, manufacturing increased its capital intensity, especially with the integration of computer technology into manufacturing systems that began in the 1990s and which resulted in higher productivity of labor (U.S. Department of Commerce, 2004). This was not due merely to the increased availability of skilled labor, since the relative wages of skilled workers increased dramatically along with their share of overall employment. Rather, the patterns of wages and employment suggest technical change resulting in increased demand for skilled labor. The onset of the global marketplace led to shifts in production overseas in order to optimally satisfy market demand. The relationship between investment flows and their underlying determinants is important for the shaping of economic development policy. Specifically, the inverse relationship between manufacturing employment and output provides an opportunity to examine whether the shift of manufacturing to more capital intensive production influenced factors important in firms' decisions regarding the geographic location of capital investment.

Location theory has a rich history of scientific research dating back to the later part of the nineteenth and early part of the twentieth centuries. Its beginnings are found in the seminal

\footnotetext{
* The views expressed here are those of the authors, and may not be attributed to the Economic Research Service, the U.S. Department of Agriculture, or Purdue University. The authors gratefully acknowledge the valuable comments of two anonymous reviewers and participants of the 2008 ERSA meetings in Liverpool, UK. Any remaining errors are the authors' responsibility.

${ }^{+}$Brown is a research economist with the Farm and Rural Household Well-Being Branch in the Resource and Rural Economics Division of the U.S. Department of Agriculture's Economic Research Service. Florax and McNamara are both Professors of Agricultural Economics at Purdue University. Florax is also Associate Professor of Spatial Economics at the Free University of Amsterdam, The Netherlands.

Contect author. Jason P. Brown, U.S. Department of Agriculture, Economic Research Service, 1800 M Street, NW, Washington, DC 20036. Email: jbrown@ers.usda.gov.
} 
works of von Thünen (1826), Weber (1929), and Lösch (1954). Renewed interest took hold in the middle decades of the 1900s in the work of Hoover (1948), McLaughlin and Robock (1949), Isard (1948) and Greenhut (1956). A common theme in this literature was a focus on empirically testing the theoretical determinants of the distribution and choice of industrial location. Empirical research has continued throughout subsequent decades to better establish the determinants of industrial location. Recent work by Guimarães, Figueiredo, and Woodward (2004) has acknowledged a renewed interest in addressing these questions following the emergence of "New Economic Geography" where agglomeration forces are purported to be important in clustering of economic activity.

Arguably, the location determinants of manufacturing investment will continue to evolve as the composition of the manufacturing industry changes (Woodward and Glickman, 1991). Blair and Premus (1987) state that the determinants of locational choices change as conditions of production change. They cite the example of U.S. appliance companies that in the mid-1960s gained large cost savings when they relocated from the North to the South. However, their review of major factors in industrial location found that the traditional economic factors of location were becoming "quantitatively less significant" (Blair and Premus, 1987, p. 80). The main contribution of this paper is as an addition to the relatively small literature on the determinants of regional investment. Our approach differs from the neoclassical investment framework used by Garofalo and Malhotra (1987), Florax and Folmer (1992), and Schalk and Untiedt (2000) in that we build on insights from location theory. The purpose of this paper is to develop and test a conceptual framework of location determinants hypothesized to impact investment flows in U.S. manufacturing. What follows in subsequent sections is a discussion of a conceptual model of location factors, a description of the data, an empirical model and estimation results, and finally conclusions and policy implications.

\section{CONCEPTUAL FRAMEWORK}

Profit maximization is often cited as the objective behind industrial location. Greenhut (1956), in one of the first works to extend Lösch's framework, describes a firm's location decision based upon a profit-maximization framework. According to Greenhut, firms choose a site from which there is sufficient demand (buyers) to achieve maximum sales served at the least possible cost. The location need not be lowest in total cost but rather a location from which monopolistic control over buyers makes it more profitable than a lower cost site as it relates to spatial monopoly power á la Hotelling (1929). The advantage of the profit-maximizing approach is that it recognizes the interaction between demand and the cost of production in location choice. It also allows for the analysis of both demand and cost factors, which may jointly influence the location decision. While somewhat restrictive, firms are assumed to have perfect information in demand and supply markets. Wasylenko and McGuire (1985) relate profit to the local price and quantity sold of the firm's output and its inputs, all of which vary across space. Product revenues and input expenditures may also vary to the extent that local areas tax or subsidize inputs and outputs (Gerking and Morgan, 1991).

An additional common framework assumes that location decisions of manufacturing investment occur as a two-stage process. McLaughlin and Robock (1949) describe firms first selecting a general area on the basis of the most important advantage of location for a given type of manufacturing. Firms then choose a specific location within the general area. McLaughlin and Robock were among the first to put forth this framework, although it was not empirically 
tested until Schmenner, Huber, and Cook (1987). Schmenner and his co-authors developed a conceptual model of location decisions that derived from the premise that a manufacturing plant's choice is based upon considerations of long-run profitability. The location factors are assumed to affect the location decision in both stages. Three categories of state-specific characteristics are hypothesized to affect the expected profitability of a plant. The first category is an indicator of the cost and supply of inputs. The second category is fiscal impacts from the government or governmental influence in general. The third category is geographic or demographic features such as amenities, and population density. Plant characteristics were also included in the framework because they are expected to change the relative influence of states' characteristics. This is similar to McLaughlin and Robock's (1949) categorization of plants into those that are oriented towards the market, materials, or labor. Location factors are expected to change in importance depending on the type of manufacturing plant.

Subsequent work by Bartik (1989), Woodward (1992), Henderson and McNamara (1997, 2000), and Lambert, Garret, and McNamara (2006a,b) has framed location of manufacturing investment as a two-stage process as well. The locations-factor approach was first suggested by Fredrich Hall in the 1900 Census of Manufactures (Jones and Woods, 2002). In the context of the location decision, the location factors can be formally expressed in a conceptual model as $X_{i}=g\left(A_{i}, S_{i}, L_{i}, I_{i}, F_{i}\right)$, where $X$ is the location choice of the investment, $i$ indexes each location, and $A, S, L, I$, and $F$ are state attributes corresponding to agglomeration forces $(A)$, market structure $(S)$, labor $(L)$, infrastructure $(I)$, and fiscal $(F)$ factors that influence a firm's cost structure. No restriction is made on the functional form of $g$, except that the function is assumed to minimize total costs. What follows is a description of each of the location factors.

Agglomeration economies refer to a well-known phenomenon. Hoover (1948) summed up agglomeration into three types: internal returns to scale which are firm-specific economies of agglomeration, localization economies which are industry-specific, and urbanization economies which are city-specific economies of agglomeration. Internal returns are firm-specific in that efficiency gains are a direct result of the size of the individual firm. Internal economies of scale may come about by a large level of investment concentrated in one particular location. Local economies occur when similar firms agglomerate across relatively proximate locations, making it easier to find a large enough pool of skilled labor or to use specialized services that are nontraded. There can also be information spillovers from close interaction among workers across firms or demand and supply-side spillovers if firms produce products used by each other or require similar inputs used in production. Glaeser et al. (1992) describe the Marshall-ArrowRomer externalities that come about from knowledge spillovers between firms in an industry when internalization leads to innovation and increased growth. Porter's (1990) theory of agglomeration due to competition embraces the same view. However, Jacobs (1969) postulates that knowledge spillovers come from outside the common industry via urban economies. Urbanization economies are associated with agglomeration of firms across different sectors (McCann, 2001). This can be observed around areas where high concentrations of manufacturing and service firms are co-located. Clustering occurs in response to large local market possibilities that exist. Agglomeration economies are hypothesized to positively impact manufacturing investment.

Market structure and nearness of markets is important for industrial products and was recognized as an important location factor rather early in the field's development. Neoclassical theory hypothesizes that production patterns are uniquely determined by relative price and 
supply factors. Demand concentration induces production concentration. Market influence is the tendency of supply to become geographically distributed according to demand (Wheat, 1986). Plant investment decisions are influenced by access to product markets, particularly when they are the source of final demand (Bartik, 1989; Woodward, 1992). Survey research has shown that market structure is consistently the most important factor in investment location decisions (Mueller and Morgan, 1962; Schmenner, Huber, and Cook, 1987; Blair and Premus, 1987; Calzonetti and Walker, 1991; Crone, 2000). Distinguishing size and density as important components of market structure, it is hypothesized that size will have a positive impact on investment, whereas density will detract from investments due to sufficiently available product demand and to excessive competition for resources.

After the cost of materials, labor costs are the largest component of the average manufacturing plant's operating expenses (Crone, 1997). Cost and availability of labor have been major factors in investment location decisions (Smith, Deaton, and Kelch, 1978; Schmenner, Huber, and Cook, 1987; Henderson and McNamara, 2000). However, the availability of skilled labor has increasingly become more important (McGranahan, 2000). This trend is expected to continue as manufacturing production becomes relatively more capital intensive. A large proportion of the manufacturing industries that are labor intensive, such as the textile industry, have been outsourced to regions of the world where unskilled labor is ubiquitous and cheap relative to the U.S. Low wage levels, high labor availability, and higher investments in human capital are expected to attract manufacturing investment, holding other factors constant.

Infrastructure aids economic development of a state by creating access to regional and national markets. Broadly speaking, infrastructure can include transportation systems and available land. Transportation has been a central focus in location theory dating back to von Thünen. New transportation technology and changing regional cost structures have tended to improve the advantages of certain areas. Throughout the literature, access to infrastructure has proven to attract manufacturing investment (Smith, Deaton, and Kelch, 1978; Bartik, 1989; Carlson, 2000; Holl, 2000; Cohen and Paul, 2004; Lambert, Garret, and McNamara, 2006a). Jones and Woods (2002) argue that the National Interstate Highway System opened industrial possibilities to the vast majority of rural America, especially in the South. Availability of land has also been cited as an important location factor (Carlson, 2000). Manufacturing firms concerned with land availability tend to avoid cities and densely populated locations. Higher levels of available infrastructure are hypothesized to attract manufacturing investment.

Fiscal policy also constitutes a common theme in industrial location literature. Direct and indirect policies affect the cost of conducting business via taxes and regulations imposed. Taxes are viewed as a deterrent to manufacturing investment in the literature (Carlton, 1983; Plaut and Pluta, 1983; Wheat, 1986; Bartik, 1989, 1992). Additionally, some surveys about plant location decisions find taxes as an important factor (Kieschnick, 1981; Hekman, 1982; Calzonetti and Walker, 1991). However, as pointed out by Papke (1991), it is effective or net taxes that are important to investment location. Oftentimes, manufacturing plants avoid or pay low property taxes due to economic development policies of state and local governments. State expenditures are also a part of fiscal factors. Higher spending is often seen as a benefit in the location literature (Plaut and Pluta, 1983; Goetz, 1997). Fiscal expenditures directed towards education, worker training, and infrastructure can impact a manufacturing plant's profitability. States with 
high tax rates are expected to deter investment while greater state expenditures are expected to attract investment provided that they are used to produce valued public goods and services.

\section{DATA DESCRIPTION}

The purpose of the conceptual model is to direct the development of the empirical model and data selection. In the empirical literature, manufacturing investment is most commonly proxied by manufacturing activity via counts of plant births, change in employment growth, or levels of capital expenditure. The least common proxy is capital expenditures, as these data are more difficult to obtain, only publicly available at the state level and at the two-digit NAICS code (31-33) level. Data on capital expenditures provide a different perspective on manufacturing investment as opposed to counts of new firms or employment growth-both of which have been in decline. While all three measures are subject to economic cycles, capital investment has generally been on an upward trend over the last 50 years (Berman, Bound and Griliches, 1994). Other studies that have used a similar measure are Benson and Johnson (1986), Papke (1987), and Gupta and Hofmann (2003). Total capital expenditures for the aggregate manufacturing sector are taken from the Annual Survey of Manufactures (ASM), produced by the U.S. Census Bureau from 1994 to 2006. ${ }^{1}$ The 48 contiguous states are used, excluding Washington D.C. as regular annual investment data are not available for this location. The investment figures are converted to real dollars using the Consumer Price Index with 2006 as the base year. $^{2}$

Manufacturers' share of employment is used as a measure of agglomeration that expresses localized economies to scale. Agglomeration due to urbanization economies is measured using the state density of total business establishments per square kilometer (Bartik, 1989; Guimarães, Figueiredo, and Woodward, 2004). Market demand structure is measured using total population and gross state product per capita (Henderson and McNamara, 2000; Davis and Schluter, 2005; Lambert, Garret, and McNamara, 2006b). Labor factors are measured using average hourly manufacturing production wage for labor cost, value of production per hour for productivity of labor, unemployment rates for labor availability, and worker union participation rates for labor climate. The productivity measure is calculated by taking the value of manufacturing shipments adding the net between beginning and ending inventories for the year. This value term is then divided by the total number of production hours. The current measure is much more appropriate than gross value added (GVA) data constructed by the Bureau of Economic Analysis (BEA), as their measure includes purchased services. Infrastructure factors are measured using kilometers of interstate highway in the state to proxy for transportation access, and the ratio of farm land to total area of a state to proxy for land availability (Henderson and McNamara, 2000). State personal income tax rates and state expenditure per capita are used as measures for fiscal factors (Plaut and Pluta, 1983; Bartik, 1989). Table 1 provides the descriptive statistics and sources of the data.

\footnotetext{
${ }^{1}$ Capital expenditures are reported at the establishment level (http://www.census.gov/mcd/asm-as1.html). Companies operating at more than one location are required to file a separate report for each location or establishment (see http://www.census.gov/prod/2002pubs/m00as-1.pdf). This ensures actual capital expenditures are accrued to the establishment location versus company headquarters.

${ }^{2}$ For comparison we also deflated the capital expenditures with the implicit price index for capital expenditures provided by BEA NIPA Table 1.1.4 (http://www.bea.gov/national/nipaweb/SelectTable.asp). The correlation between the series deflated with CPI and implicit price index for capital expenditures was 0.998 . We chose to use the CPI-deflated series to maintain consistency with other deflated variables used in the analysis.
} 
TABLE 1. Descriptive Statistics for Variables Used in the Study

\begin{tabular}{llrrrr}
\hline Variable & Definition & Mean & Std Dev & Min & Max \\
\hline inv $^{1}$ & Manuf. investment (\$ Millions)* & $3,409.26$ & $4,108.99$ & 49.67 & $53,129.12$ \\
memp $^{2}$ & Manuf. share of total employment $(\%)$ & 12.79 & 4.87 & 3.40 & 25.76 \\
ua $^{2}$ & Establishment density (no. per square km) & 1.86 & 2.63 & 0.07 & 12.58 \\
pwage $^{1}$ & Prod. employ. average hourly wage (\$ per hour) & 17.52 & 1.85 & 13.01 & 23.41 \\
product $^{1}$ & Value of production per hour (\$ Thousands) & 220.49 & 71.16 & 114.51 & 855.76 \\
pop $^{3}$ & Population (in Thousands) & $5,846.21$ & $6,236.83$ & 85.16 & $36,249.87$ \\
gspc $^{4}$ & Gross state product per capita (\$ Thousands) & 38.38 & 7.07 & 26.09 & 70.78 \\
unempr $^{5}$ & Unemployment rates (\%) & 4.70 & 1.10 & 2.30 & 8.10 \\
union $^{5}$ & Unionization rates (\%) & 11.81 & 5.34 & 2.30 & 27.70 \\
interst $^{6}$ & Kilometers of interstate highway & $1,514.75$ & 936.87 & 64.37 & $5,204.48$ \\
avland $^{7}$ & Farm area / total area (\%) & 41.83 & 24.55 & 6.22 & 93.72 \\
pit $^{4}$ & State personal income tax rate & 2.14 & 1.10 & 0.00 & 4.48 \\
stec $^{2}$ & Govt. expenditures per capita (\$Thousands) & 4.17 & 0.94 & 3.10 & 8.15 \\
\hline
\end{tabular}

* Currency values are in real dollars, ${ }^{1}$ Annual Survey of Manufactures 1994-2006, ${ }^{2}$ County B.P., U.S. Census Bureau

${ }^{3}$ Population Division, U.S. Census Bureau, ${ }^{4}$ Bureau of Economic Analysis, Regional Economic Information System

${ }^{5}$ Bureau of Labor Statistics, ${ }^{6}$ U.S. Department of Transportation, ${ }^{7}$ National Agricultural Statistics Services, $N=48, T=12$.

What follows is a discussion of the data directly related to manufacturing activity. Investment ranges over the time period from $\$ 49$ million (Wyoming in 2003) to $\$ 53.1$ billion (Ohio in 1996) with an average of $\$ 3.4$ billion across all states and years. The states having the highest investment in all years are California, Michigan, Ohio, and Texas. This is somewhat expected as Michigan and Ohio have traditionally been strong manufacturing states, while California and Texas hold a large share of computer and electronics manufacturing. Manufacturing share of employment provides insight as to where employment is heavily concentrated; the average employment share is 12 percent with the range being 3 to 26 percent. Indiana had the highest employment percentage in all years with the exception of North Carolina in 1995. States with the highest percentages have typically been Indiana, Michigan, and Ohio in the Midwest, and Arkansas, Mississippi, Alabama, North Carolina and South Carolina in the South. The average hourly production wage ranges from $\$ 13.01$ to $\$ 23.41$ with an average of $\$ 17.52$. Wages are typically higher in Michigan, Indiana, and Ohio in the Midwest, Connecticut and Delaware in the Northeast, and Washington and Wyoming in the West. Moreover, wages are lower in the South with exception of Louisiana, and in some years West Virginia. Value of manufacturing production measured in thousands of dollars per production hour ranges from $\$ 114$ to $\$ 855$ with an average of $\$ 220$. The highest value is in Louisiana in 2006. Prior to 2005 and Hurricane Katrina, Louisiana still had the highest value of production at \$611 in 2004.

Looking at these data over time provides some insight on interesting trends in manufacturing. Figure 1 shows investment measured in millions of real dollars for the entire U.S. Expansion in investment can be seen during the mid to late 1990s, which coincides with the macroeconomic expansion during that period. Beginning in 2000, a contraction in investment occurred which worsened after 2001, coinciding with the economic recession during the same period. The level of investment appears to flatten out by 2006. Figure 2 illustrates two additional trends in total U.S. manufacturing employment and productivity as measured by real value of output per production hour. Manufacturing employment maintained a steady decline while productivity increased. In light of these trends, the increasing need for skilled versus unskilled 
labor for manufacturing production seems very plausible and has been supported in the literature (McGranahan, 2000).

FIGURE 1. U.S. Manufacturing Investment

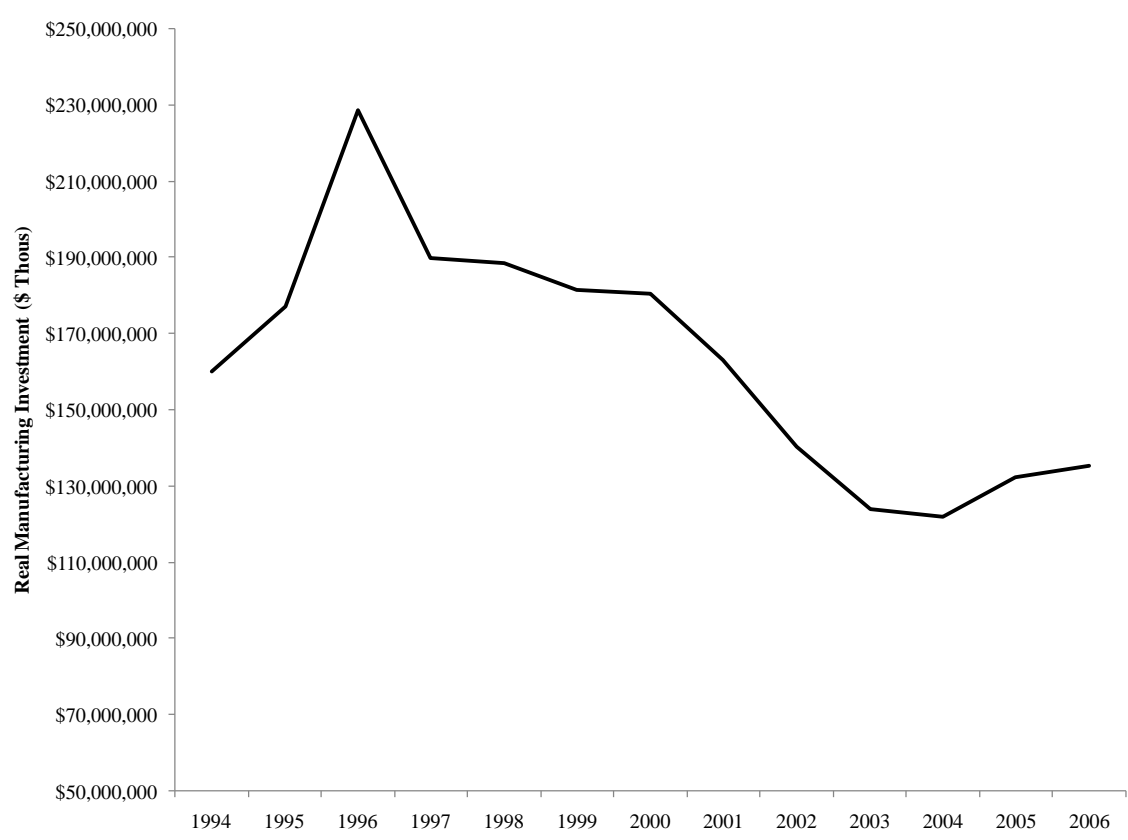

FIGURE 2. U.S. Manufacturing Employment and Output

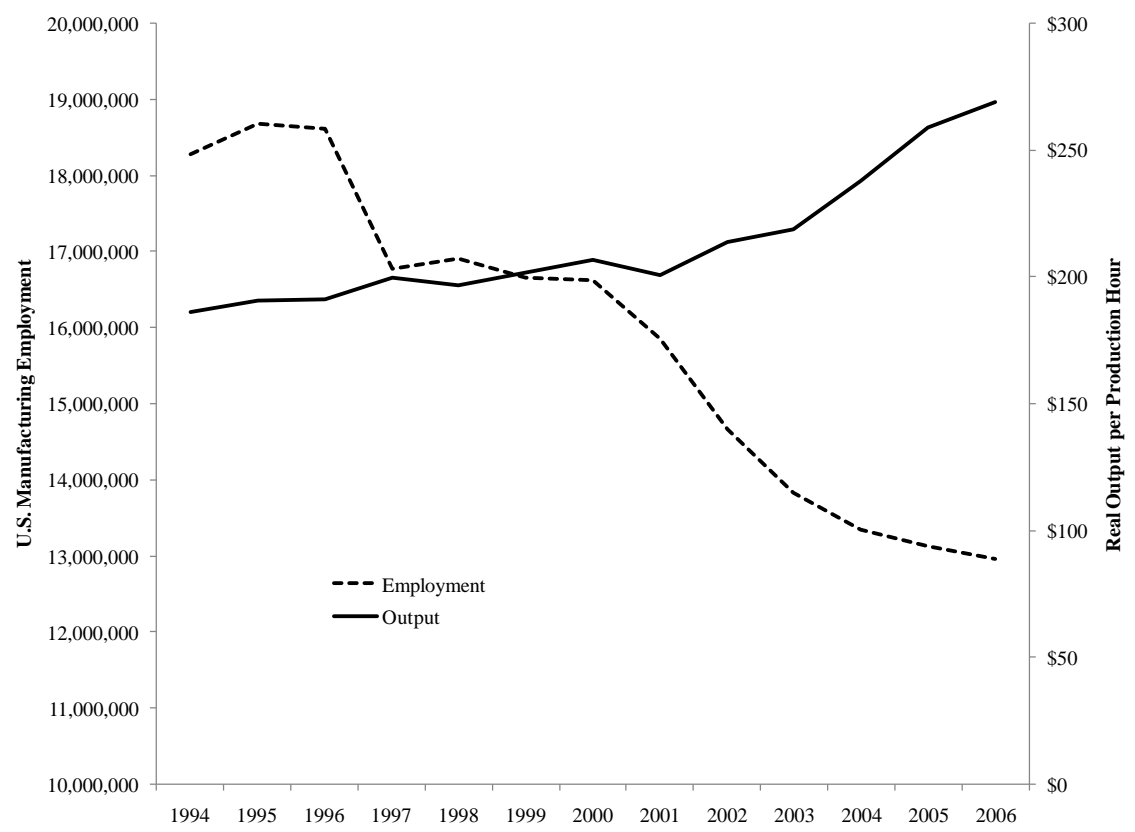

(C) Southern Regional Science Association 2011. 


\section{SPATIAL DEPENDENCE AND SPATIAL PROCESS MODELS}

Traditional industrial location models have tended to ignore the possibility of spatial spillovers in investment from one region to the next. There are a few exceptions, but they have tended to focus on counts of firms versus capital expenditures. For example, Lambert, Garret and McNamara (2006a) incorporated spatial processes using geographically weighted regression (GWR) and Poisson regressions when looking at location factors of counts of new manufacturing firms. A distance decay function was used which applies geostatistical concepts, the direct approach for modeling spatial dependence. Klier and McMillen (2008) use a generalized method of moments (GMM) estimator of the spatial logit model to explain clustering of auto supplier plants. Lambert, Garret and McNamara (2006b), in looking at food manufacturing investment, used a spatial probit model to estimate a spatial lag model to account for spillover effects.

When spatial dependence is present and appropriately modeled, more accurate estimates of the relevance of different location factors can be obtained. Spatial dependence is routinely modeled as an additional covariate in the form of a spatially lagged dependent variable $W y$, or in the error structure $\varepsilon=\lambda W \varepsilon+\mu$, where $\mu$ is an i.i.d. disturbance term. Some neighboring criterion determines the structure of the spatial weights matrix $W$, which is routinely based on a contiguity (queen or rook) or distance criterion (Anselin, 2002). The weights in $W$ are usually rowstandardized so that the elements of each row sum to one. The spatial lag model is utilized when importance is granted to the presence of spatial interaction. Spatial dependence in the error term is modeled in the spatial error model and is commonly referred to as nuisance dependence (Anselin, 2003). We chose not to use the spatial error model due its lack of interpretation of spatial dependence and, more importantly, its susceptibility to omitted variables. LeSage and Pace (2009) highlight the latter point. They provide two reasons for using spatial process models that include a spatially lagged dependent variable. First, spatial dependence can be viewed as a long-run equilibrium of a spatiotemporal process. Such a process can be expressed as:

(1) $y_{t}=\rho W y_{t-1}+X \beta+\varepsilon_{t}$,

where $t$ indexes time, $W y_{t-1}$ is an $N \times 1$ vector of a spatiotemporally lagged dependent variable, with $\rho$ as a spatial autoregressive parameter, $X$ is an $N \times K$ matrix containing exogenous covariates, and $\varepsilon$ is an $N \times 1$ vector of well-behaved error terms. The use of a spatial lag operator creates a weighted average of the $y$-variables at neighboring locations (Anselin, 2003). The time subscript is omitted on the explanatory variables contained in $X$, indicating a situation where location determinants of investment are constant, or they change slowly over time. Using the recursive relationship implied in (1) the steady-state equilibrium can be obtained by taking the expected value of $y_{t}$ after $T$ periods assuming $T \rightarrow \infty$ (LeSage and Pace, 2009). The autoregressive process that follows is shown in (2) and the corresponding reduced form in (3):

(2) $y_{t}=\rho W y_{t}+X_{t} \beta+\varepsilon_{t}$,

(3) $y_{t}=(I-\rho W)^{-1}\left[X_{t} \beta+\varepsilon_{t}\right]$.

In this specification an investment decision in a given state is connected to all other investment decisions by the spatial multiplier $(I-\rho W)^{-1}$, which is applied to the exogenous variables and the error term (Anselin, 2003). As a result, changes in $X$ bring about a series of changes in the location of investment flows, which results in a new steady-state equilibrium. 
This model can, for instance, quantify how changes in transportation infrastructure at the state level would impact investment flows to all other states in the long run.

Omitted variables are the second reason given by LeSage and Pace (2009) for including a spatially lagged dependent. They show that spatially dependent omitted variables result in a model with a design matrix containing spatially lagged versions of the dependent and the exogenous variables, known as a spatial Durbin model (Anselin, 1988). The set of equations resulting in a spatial Durbin model (SDM) can be expressed as:

(4) $y=X \beta+\eta$

(5) $\eta=\rho W \eta+\varepsilon$

(6) $\varepsilon=X \gamma+u$,

where $y$ is an $N \times 1$ vector of observations on the dependent variable, $X$ an $N \times K$ matrix of observations on the explanatory variables, $\eta$ is an $N \times 1$ vector of a spatially correlated omitted variable following a spatial autoregressive process with autoregressive coefficient $\rho$, and $u$ is an $N \times 1$ vector of i.i.d. random error terms. Equation (4) shows that the omitted variable is correlated with $X$ when $\gamma \neq 0$. Using the relationships between (3)-(5) and the cofactor restrictions LeSage and Pace (2009) show that the resulting model and data generating process are:

(7) $y=\rho W y+X \beta+W X \gamma+u$,

(8) $y=(I-\rho W)^{-1}[X \beta+W X \gamma+u]$,

containing a spatial lag of the dependent variable and the exogenous covariates. The implications of (7) and (8) in the present study are that investment flows in a particular state are a function of the weighted average of neighboring states' investments $(W y)$, location determinants $(X)$, as well as the weighted average of neighboring states' location determinants $(W X)$. We now turn to specification of the spatial structure in state level investment flows. An example of an omitted variable that might be correlated with other location determinants is the unobservable composition of the manufacturing industry in each state. Some industries may be in decline, while others are remaining constant or expanding. Moreover, the composition of the manufacturing industry in each state could be related to neighboring states, i.e. the automotive industry in the Midwest states.

In the empirical analysis we operationalized the model given in Equations (7) and (8) using panel data. The spatial weights matrix is defined as a row-standardized first-order queen matrix, assuming that the spatial relationships remain constant over time (Anselin et al., 2008). The weights matrix can then be specified as:

(9) $W_{N T}=I_{T} \otimes W_{N}$,

where the Kronecker product of an identity matrix $I$ and the cross-sectional weight matrix $W$ results in a block-diagonal weight matrix $W_{N T}$. A cross-sectionally stacked variant of the spatial Durbin model can be used to exploit the available panel data. Time fixed effects may be included to account for economic cycles and trends in investment flows. Temporally lagged exogenous covariates $\left(X_{t-1}\right)$ are used to avoid potential endogeneity of contemporaneous variables in the design matrix. The operational model that follows and the corresponding data generating process are:

(C) Southern Regional Science Association 2011. 


$$
\begin{aligned}
& y_{t}=\rho\left(I_{t} \otimes W_{n}\right) y_{t}+l_{t} \alpha+X_{t-1} \beta+W X_{t-1} \gamma+u_{t} \\
& y_{t}=\left[I_{t} \otimes\left(I_{n}-\rho W_{n}\right)\right]^{-1}\left[{ }_{t} \alpha+X_{t-1} \beta+W X_{t-1} \gamma+u_{t}\right]
\end{aligned}
$$

where the spatial multiplier is now an $N T$ by $N T$ matrix, and $l_{t}$ are time fixed effects. The stacked version of the spatial Durbin model can be estimated with an appropriate maximum likelihood estimator.

Industrial location models investigating location decisions or flows of firm activity are routinely expressed in log-linear form in the case of counts of new establishments, or in double$\log$ form when using levels of capital expenditure (Carlton, 1983; Guimarães, Figueiredo and Woodward, 2004; Gupta and Hofmann, 2003). We use the double-log specification because of the advantage of interpreting the regression coefficients as elasticity measures. The interpretation of the model is explained in the next section.

\section{EMPIRICAL RESULTS}

We assess the importance of the set of location determinants described in Section 2 by means of a dataset on manufacturing investments in the lower 48 U.S. states during the time period 1995-2006. We use a cross-regressive model, ${ }^{3}$ containing only the spatially lagged exogenous variables, and the spatial Durbin model, which are estimated using the ordinary least squares estimator and the maximum likelihood estimator for the spatial lag model, respectively. The models were estimated in R 2.7.2, using the spdep package (Bivand, 2009). For both models we assume a queen contiguity matrix to define neighboring states in $W$ (Anselin, 2002). Our findings are generally consistent with previous studies concerning the location determinants of manufacturing investment. We find a positive impact associated with local agglomeration economies, market size, labor productivity, and transportation infrastructure (Carlton, 1983; Bartik, 1985; Coughlin, Terza, and Arromdee, 1991; Woodward, 1992; Levinson, 1996; Head, Reis and Swenson, 1999; Becker and Henderson, 2000; Coughlin and Segev, 2000; List, 2001; Guimarães, Figueiredo, and Woodward, 2004).

The regression coefficients and their associated standard errors are reported in Table 2. The coefficients from both models are similar in sign, magnitude, and significance. Overall the models explain about 94 percent of the variation in the log of investments. The time effects reveal a significant downturn in investment relative to 1995. The cross-regressive model contains direct $(X)$ and indirect effects $(W X)$ for each of the location determinants. A one-percent increase in a state and its neighbors' manufacturing share of employment raises the investment level by 1.1 percent $(0.929+0.155)$ due to the direct impact of localized agglomeration in the state and the indirect impact of local agglomeration in neighboring states. Similarly, a one-percent increase in the populations of a state and in its neighbors increases manufacturing investment by 17.2 percent $(11.7+5.5)$. The interpretation of the results for the spatial Durbin model is slightly more involved. The magnitude of the autoregressive parameter is -0.112 , which indicates negative spatial spillover effects. Generally, this implies that states with high levels of investment will have neighboring states with lower levels of investment, and vice versa. This

\footnotetext{
${ }^{3}$ A cross-regressive model is the long-standing term used to describe a model containing spatially lagged explanatory variables that can be estimated with ordinary least squares (Florax and Folmer, 1992; Anselin, 2002, 2003). More recently, LeSage and Pace (2009) refer to this as the SLX model (spatial lag of X-variables model).
} 
parameter however, interacts with the other explanatory variables. As a result, the coefficients of the spatial Durbin model cannot be compared directly to coefficients from a model that does not contain a spatially lagged dependent variable.

TABLE 2. Model Estimates from Cross-regressive and Spatial Durbin Models

\begin{tabular}{|c|c|c|c|c|}
\hline Variable & $\beta_{\text {OLS }}^{\mathrm{a}}$ & $\beta_{\mathrm{SDM}}$ & S.E. ${ }^{b}$ OLS & S.E.SDM \\
\hline constant & $-37.952 * * *$ & $-41.086 * * *$ & 4.920 & 4.871 \\
\hline Wy & ------- & $-0.112 * *$ & ------- & 0.058 \\
\hline lnmemp $_{t-1}$ & $0.929 * * *$ & $0.935 * * *$ & 0.053 & 0.053 \\
\hline $\operatorname{lnua}_{t-1}$ & 0.039 & 0.038 & 0.041 & 0.041 \\
\hline $\operatorname{lngspc_{t-1}}$ & $0.271 * *$ & $0.273 * *$ & 0.127 & 0.127 \\
\hline $\operatorname{lnpop}_{t-1}$ & $11.681 * * *$ & $11.758 * * *$ & 1.104 & 1.101 \\
\hline $\operatorname{lnpwage}_{t-1}$ & $0.630 * *$ & $0.631 * *$ & 0.266 & 0.264 \\
\hline $\operatorname{lnprod}_{t-1}$ & $0.703 * * *$ & $0.704 * * *$ & 0.124 & 0.122 \\
\hline lnunempr $_{t-1}$ & -0.021 & -0.020 & 0.104 & 0.104 \\
\hline lnunion $_{t-1}$ & -0.079 & -0.075 & 0.055 & 0.055 \\
\hline lninterst $_{t-1}$ & $0.244 * * *$ & $0.242 * * *$ & 0.073 & 0.072 \\
\hline lnavland $_{t-1}$ & -0.027 & -0.033 & 0.057 & 0.056 \\
\hline lnpit $_{t-1}$ & 0.011 & 0.010 & 0.009 & 0.009 \\
\hline lnstec $_{t-1}$ & -0.116 & -0.104 & 0.127 & 0.126 \\
\hline$W \times \operatorname{lnmemp}_{t-1}$ & $0.155^{*}$ & $0.257 * * *$ & 0.081 & 0.081 \\
\hline$W \times \ln u a_{t-1}$ & $-0.151 * *$ & $-0.154 * *$ & 0.065 & 0.065 \\
\hline$W \times \operatorname{lngspc_{t-1}}$ & -0.266 & -0.257 & 0.222 & 0.222 \\
\hline$W \times \operatorname{lnpop}_{t-1}$ & $5.547 * *$ & $6.976 * * *$ & 2.193 & 2.174 \\
\hline$W \times \operatorname{lnpwag} e_{t-1}$ & 0.135 & 0.210 & 0.479 & 0.477 \\
\hline$W \times \operatorname{lnprod}_{t-1}$ & 0.214 & 0.280 & 0.235 & 0.233 \\
\hline$W \times$ lnunempr $_{t-1}$ & $-0.311 * *$ & $-0.306 * *$ & 0.150 & 0.149 \\
\hline$W \times$ lnunion $_{t-1}$ & 0.048 & 0.036 & 0.091 & 0.090 \\
\hline$W \times$ lninterst $_{t-1}$ & -0.111 & -0.076 & 0.154 & 0.153 \\
\hline$W \times$ lnavland $_{t-1}$ & $-0.192 * * *$ & $-0.199 * * *$ & 0.071 & 0.070 \\
\hline$W \times$ lnpit $_{t-1}$ & $-0.069 * * *$ & $-0.067 * * *$ & 0.023 & 0.022 \\
\hline$W \times \operatorname{lnstec}_{t-1}$ & 0.410 & 0.430 & 0.308 & 0.307 \\
\hline$t_{96}$ & -0.035 & -0.038 & 0.096 & 0.096 \\
\hline$t_{97}$ & 0.023 & 0.029 & 0.057 & 0.056 \\
\hline$t_{98}$ & 0.030 & 0.039 & 0.071 & 0.071 \\
\hline$t_{99}$ & -0.007 & 0.001 & 0.082 & 0.081 \\
\hline$t_{00}$ & -0.030 & -0.021 & 0.097 & 0.096 \\
\hline$t_{01}$ & $-0.196 *$ & $-0.202 *$ & 0.104 & 0.103 \\
\hline$t_{02}$ & $-0.225 * *$ & $-0.244 * *$ & 0.104 & 0.103 \\
\hline$t_{03}$ & $-0.342 * * *$ & $-0.382 * * *$ & 0.116 & 0.116 \\
\hline$t_{04}$ & $-0.276^{* *}$ & $-0.307 * * *$ & 0.117 & 0.116 \\
\hline$t_{05}$ & $-0.274 * *$ & $-0.301 * *$ & 0.118 & 0.117 \\
\hline$t_{06}$ & $-0.288 * *$ & $-0.311 * * *$ & 0.114 & 0.113 \\
\hline Adjusted $R^{2}$ & 0.942 & 0.946 & & \\
\hline$F$-Statistic & 268.9 & 270.6 & & \\
\hline
\end{tabular}

(C) Southern Regional Science Association 2011. 
TABLE 3. Direct and Indirect Effects Estimates

\begin{tabular}{|c|c|c|c|c|}
\hline & $\begin{array}{l}\text { Direct } \\
\mathrm{OLS}^{\mathrm{a}}\end{array}$ & $\begin{array}{l}\text { Direct } \\
\text { SDM }^{\mathrm{b}}\end{array}$ & $\begin{array}{c}\text { Indirect } \\
\text { OLS }\end{array}$ & $\begin{array}{c}\text { Indirect } \\
\text { SDM }\end{array}$ \\
\hline $\operatorname{lnmemp}_{t-1}$ & $\begin{array}{l}0.929 * * * \\
(0.053)\end{array}$ & $\begin{array}{l}0.944 * * * \\
(0.001)\end{array}$ & $\begin{array}{c}0.155^{*} \\
(0.081)\end{array}$ & $\begin{array}{l}-0.146 * * * \\
(0.002)\end{array}$ \\
\hline $\operatorname{lnua}_{t-1}$ & $\begin{array}{c}0.039 \\
(0.041)\end{array}$ & $\begin{array}{l}0.042 * * * \\
(0.024)\end{array}$ & $\begin{array}{l}-0.151 * * \\
(0.065)\end{array}$ & $\begin{array}{c}-0.007 * * * \\
(2.0 \mathrm{e}-04)\end{array}$ \\
\hline $\operatorname{lngspc_{t-1}}$ & $\begin{array}{l}0.271 * * \\
(1.27)\end{array}$ & $\begin{array}{l}0.268 * * * \\
(0.004)\end{array}$ & $\begin{array}{c}-0.266 \\
(0.222)\end{array}$ & $\begin{array}{c}-0.027 * * * \\
(7.0 \mathrm{e}-04)\end{array}$ \\
\hline $\operatorname{lnpop}_{t-1}$ & $\begin{array}{l}11.681 * * * \\
(1.104)\end{array}$ & $\begin{array}{l}11.831 * * * \\
(0.026)\end{array}$ & $\begin{array}{l}5.547 * * \\
(2.193)\end{array}$ & $\begin{array}{l}-2.093 * * * \\
(0.024)\end{array}$ \\
\hline $\operatorname{lnpwage}_{t-1}$ & $\begin{array}{l}0.630 * * \\
(0.266)\end{array}$ & $\begin{array}{l}0.636 * * * \\
(0.007)\end{array}$ & $\begin{array}{c}0.135 \\
(0.479)\end{array}$ & $\begin{array}{c}-0.103 * * * \\
(0.002)\end{array}$ \\
\hline $\operatorname{lnprod}_{t-1}$ & $\begin{array}{l}0.703 * * * \\
(0.124)\end{array}$ & $\begin{array}{l}0.712 * * * \\
(0.003)\end{array}$ & $\begin{array}{c}0.214 \\
(0.235)\end{array}$ & $\begin{array}{c}-0.120 \text { *** } \\
(0.001)\end{array}$ \\
\hline lnunempr $_{t-1}$ & $\begin{array}{c}-0.021 \\
(0.104)\end{array}$ & $\begin{array}{l}-0.023 * * * \\
(0.003)\end{array}$ & $\begin{array}{l}-0.311 * * \\
(0.150)\end{array}$ & $\begin{array}{l}0.018 * * * \\
(5.0 \mathrm{e}-04)\end{array}$ \\
\hline lnunion $_{t-1}$ & $\begin{array}{c}-0.079 \\
(0.055)\end{array}$ & $\begin{array}{l}-0.057 * * * \\
(0.002)\end{array}$ & $\begin{array}{c}0.048 \\
(0.091)\end{array}$ & $\begin{array}{l}0.009 * * * \\
(2.8 \mathrm{e}-04)\end{array}$ \\
\hline lninterst $_{t-1}$ & $\begin{array}{l}0.244 * * * \\
(0.073)\end{array}$ & $\begin{array}{l}0.245^{* * *} \\
(0.002)\end{array}$ & $\begin{array}{l}-0.111 \\
(0.154)\end{array}$ & $\begin{array}{c}-0.034 * * * \\
(5.1 \mathrm{e}-04)\end{array}$ \\
\hline lnavland $_{t-1}$ & $\begin{array}{c}-0.027 \\
(0.057)\end{array}$ & $\begin{array}{c}-0.036 * * * \\
(0.001)\end{array}$ & $\begin{array}{l}-0.192 * * * \\
(0.071)\end{array}$ & $\begin{array}{l}0.015 * * * \\
(2.8 \mathrm{e}-04)\end{array}$ \\
\hline lnpit $_{t-1}$ & $\begin{array}{c}0.011 \\
(0.009)\end{array}$ & $\begin{array}{c}0.009 * * * \\
(2.3 \mathrm{e}-04)\end{array}$ & $\begin{array}{l}-0.069 * * * \\
(0.023)\end{array}$ & $\begin{array}{l}0.002 * * * \\
(6.3 \mathrm{e}-05)\end{array}$ \\
\hline $\operatorname{lnstec}_{t-1}$ & $\begin{array}{c}-0.116 \\
(0.127) \\
\end{array}$ & $\begin{array}{c}-0.104 * * * \\
(0.003)\end{array}$ & $\begin{array}{c}0.410 \\
(0.308) \\
\end{array}$ & $\begin{array}{c}-0.005 * * * \\
(7.5 \mathrm{e}-05) \\
\end{array}$ \\
\hline
\end{tabular}

${ }^{\mathrm{a}}$ Standard errors are reported in parentheses. ${ }^{\mathrm{b}} \mathrm{SDM}$ effects are from bootstrap procedure. $* * *$, **, and * represent significance at the 1,5 , and 10 percent level respectively

Marginal effects from a change in a coefficient can be decomposed into direct and indirect effects as illustrated by LeSage and Pace (2009). To illustrate this point, the partial derivative of the spatial Durbin model in (8) with respect to a particular explanatory variable is:

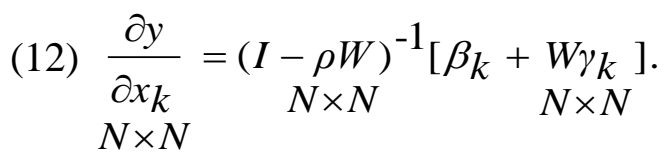

The partial derivative results in an $N$-by- $N$ matrix of marginal effects. The impact on the dependent variable from a change in a covariate can be summarized in three ways (LeSage and Pace, 2009). The first is the average total effect on an observation. The row sums represent the total effect on each observation from changing the $k$-th explanatory by the one unit across all observations. Dividing the row sums by the number of observations yields the average total effect. The second impact is referred to as the direct effect, which is the effect of changes in the $i$-th observation of $x_{k}$ on $y_{i}$. The average direct effect is measured by summing the trace elements of the $N$ by $N$ matrix in (12) and dividing by the number of observations. The third impact is referred to as the indirect effect, which constitutes feedback effects through neighbors. Average direct and indirect effects of the cross-regressive and the spatial Durbin model are reported in 
Table 3. The standard errors of the direct and indirect effects for the spatial Durbin model were calculated using a bootstrap method with 1,000 draws. The direct effects are similar between the two models, and changes in the direction of the effects are not apparent.

The indirect effects, however, are drastically different between the two types of models due to the fact that spillover effects in the cross-regressive model only accrue to local neighbors while in the spatial Durbin model they extend throughout the spatial system. These extensive spillover and feedback effects are related to the connectivity of the regions and the size of the spatial multiplier. These differences noticeably impact the results due to the negative coefficient on $W y$. It should be noted that when $\rho$ is very small or close to zero, the spatial Durbin model collapses to the cross-regressive model. However, if $\rho$ is statistically significant results from the cross-regressive model will be biased and inconsistent (Anselin, 1988, pp.58). As a result, the spatial Durbin model provides more reliable estimates of the total effect on investment from a change in a particular location factor. For example, increasing the production wages by 1 percent has a positive direct effect in both models, but has a negative average indirect effect in the spatial Durbin model of -0.1 percent. The interpretation of this result is that on average increasing wages in state $i$ is positive, but the spillover on neighboring states is negative, so that the investment level decreases due to the competitive force which pulls investment away. The same interpretation holds true for changes in urban agglomeration, GDP per capita, labor productivity, and interstate highway infrastructure. Reducing unemployment rates and unionization rates have positive direct effects, but negative indirect effects.

The most striking difference between the two models is the indirect effects on population. The indirect (spatial spillover) effect in the cross-regressive model has a positive and significant effect, suggesting that increasing a state's population by 1 percent produces a cumulative increase in the investment level of 5.5 percent over all neighboring states (on average over the space-time sample). In contrast, the average indirect (spillover) effect of a 1 percent population increase in the SDM shows a reduction in neighboring states' investment levels cumulating to 2.1 percent decrease across all neighbors. An important point is that the indirect effects reported here are cumulative across all neighbors, so the impact on any individual neighboring state will be much smaller than the 5.5 percent or 2.1 percent stated above (see LeSage and Pace, 2009 for details). More government spending at the state and local level seems to deter manufacturing investment according to the direct and indirect effects of the spatial Durbin model. The personal income tax rate of the state has positive and significant direct and indirect effects, which is maybe at odds with expectations. The positive direction of the effect may be a result of firms being sensitive to other kinds of taxes levied by states, or due to the fact that firms positively value the supply of public goods financed through levying higher taxes.

\section{CONCLUSIONS}

This paper contributes to the relatively small literature on the determinants of regional investment. A conceptual model of location determinants is developed, which considers the importance of agglomeration economies, market structure, labor availability and productivity, infrastructure, and fiscal determinants. A cross-regressive model containing spatially lagged explanatory variables and a spatial Durbin model containing spatially lagged explanatory variables, including the lagged dependent variable, are estimated. We find a positive impact associated with local agglomeration economies, market size, labor productivity, and transportation infrastructure. Spatial spillovers are found to be of a competitive nature at the 
state level, implying that a factor that attracts more investment to a particular state is associated with lower investments in neighboring states. Market structure was found to be the most important factor in investment location, which suggests that the manufacturing sector as a whole still prefers to locate near demand centers. One potential policy implication is that policy makers should focus on economic development policies that attract people if they wish to attract manufacturing investment. Moreover, the attempts to increase the investment flows in a particular state may have competitive implications for investment flows to neighboring states. This may point to the possibility of unintended consequences on the impact of states' economic development policies as well as any federal transfers used to attract investment.

The cross-regressive and spatial Durbin model results show the significant relationships between neighboring states' location determinants and the potential of spillover and feedback effects from changes in location attributes on investment flows, respectively. We find that localized and urban agglomeration economies, market demand, population, wages, labor productivity, and interstate infrastructure on average have positive direct effects on a state's investment flows, but negative effects on neighboring states. These findings illustrate the richness of the spatial Durbin model in quantifying the relationships between state level investment flows; a feature not previously captured in the literature.

One limitation in this study is the level of spatial aggregation. Heterogeneity within the each state is likely to be of the same magnitude as across states. However, manufacturing investment data (i.e. capital expenditures) at a lower level of spatial aggregation are not readily available. A low level of spatial dependence is also likely due to the high level of spatial aggregation. Future research should consider how location factors also effect manufacturing investment by sector and size of the firm over time. These are likely to be different if the firm is demand-, supply-, or footloose-oriented with respect to the marketplace. The size of the firm is also likely to have an impact, with smaller firms potentially being more inelastic to location factors.

\section{REFERENCES}

Anselin, Luc. (1988) Spatial Econometrics: Methods and Models. Kluwer Academic Publishers: Amsterdam.

(2002) "Under the Hood Issues in the Specification and Interpretation of Spatial Regression Models," Agricultural Economics, 27, 247-267.

. (2003) "Spatial Externalities, Spatial Multipliers, and Spatial Econometrics," International Regional Science Review, 26, 153-166.

Anselin, Luc., Julie Le Gallo, and Hubert Jayet. (2008) “Spatial Panel Econometrics," in Láslow Mátyás and Patrick Sevestre (eds.), The Econometrics of Panel Data. Springer: Berlin, pp. 627-662

Bartik, Timothy J. (1985) "Business Location Decisions in the United States: Estimates of the Effects of Unionization, Taxes, and Other Characteristics of States," Journal of Business and Economic Statistics, 3, 14-22.

. (1989) "Small Business Start-Ups in the United States: Estimates of the Effects of Characteristics of States," Southern Economic Journal, 55, 1004-1018.

(C) Southern Regional Science Association 2011. 
(1992) "The Effects of State and Local Taxes on Economic Development: A Review of Recent Research,” Economic Development Quarterly, 6, 102-111.

Becker, Randy and Vernon Henderson. (2000) "Effects of Air Quality Regulations on Polluting Industries," Journal of Political Economy, 108, 379-421.

Benson, Bruce L. and Ronald N. Johnson. (1986) "The Lagged Impact of State and Local Taxes on Economic Activity and Political Behavior," Economic Inquiry, 24, 389-401.

Berman, Eli, John Bound, and Zvi Griliches. (1994) "Changes in Demand for Skilled Labor within U.S. Manufacturing: Evidence from the Annual Survey of Manufactures," Quarterly Journal of Economics, 109, 367-397.

Bivand, Roger. (2009) “spdep: Spatial Dependence: Weighting Schemes, Statistics and Models," http://cran.r-project.org/web/packages/spdep/spdep.pdf.

Blair, John P. and Robert Premus. (1987) "Major Factors in Industrial Location: A Review," Economic Development Quarterly, 1, 72-85.

Calzonetti, Frank J. and Robert T. Walker. (1991) "Factors Affecting Industrial Location Decisions: A Survey Approach," in Henry W. Herzog and Alan M. Schlottmann (eds.), Industry Location and Public Policy. University of Tennessee Press, Knoxville, pp. 221240.

Carlson, Virginia. (2000) "Studying Firm Locations: Survey Responses vs. Econometric Models," Journal of Regional Analysis \& Policy, 30, 1-22.

Carlton, Dennis W. (1983) "The Location and Employment Choices of New Firms: An Econometric Model with Discrete and Continuous Endogenous Variables," Review of Economics and Statistics, 14, 209-220.

Cohen, Jeffery P. and Catherine M. Paul. (2004) "Agglomeration Economies and Industry Location Decisions: The Impacts of Spatial and Industrial Spillovers," Regional Science and Urban Economics, 35, 215-237.

Coughlin, Cletus C. and Eran Segev. (2000) "Location Determinants of New Foreign-Owned Manufacturing Plants," Journal of Regional Science, 40, 323-351.

Coughlin, Cletus C., Joseph V. Terza, and Vachira Arromdee. (1991) "State Characteristics and the Location of Foreign Direct Investment within the United States," Review of Economics and Statistics, 73, 675-683.

Crone, Theodore M. (1997) "Where Have All the Factory Jobs Gone-and Why?," Business Review, Federal Reserve Bank of Philadelphia. May/June, 1-16. (2000) "A New Look at Economic Indexes for the States in the Third District," Business Review, Federal Reserve Bank of Philadelphia. November/December, 3-14.

Davis, David E. and Gerald E. Schluter. (2005) "Labor-Force Heterogeneity as a Source of Agglomeration Economies in an Empirical Analysis of County-level Determinants of Food Plant Entry," Journal of Agricultural and Resource Economics, 30, 480-501.

Florax, Raymond J.G.M. and Henk Folmer. (1992) "Specification and Estimation of Spatial Linear Regression Models: Monte Carlo Evaluation of Pre-Test Estimators," Regional Science and Urban Economics, 22, 405-432.

(C) Southern Regional Science Association 2011. 
Garofalo, Gasper A. and Devinder M. Malhotra. (1987) "Regional Capital Formation in U.S. Manufacturing during the 1970s," Journal of Regional Science, 27, 391-401.

Gerking, Shelby and William Morgan. (1991) "Measuring Effects of Industrial Location and State Economic Development Policy: A Survey," in Henry W. Herzog and Alan M. Schlottmann (eds.), Industry Location and Public Policy. University of Tennessee Press: Knoxville, TN, pp. 31-56.

Glaeser, Edward L., Heidi D. Kallal, Jose A. Scheinkman, and Andrei Shleifer. (1992) "Growth in Cities," Journal of Political Economy, 100, 1126-1151.

Goetz, Stephan. (1997) "State- and County-level Determinants of Food Manufacturing Establishment Growth: 1987-1993," American Journal of Agricultural Economics, 79, 838-850.

Greenhut, Melvin L. (1956) Plant Location in Theory and in Practice. University of North Carolina Press: Chapel Hill.

Guimarães, Paulo, Octavio Figueiredo, and Douglas Woodward. (2004) "Industrial Location Modeling: Extending the Random Utility Framework," Journal of Regional Science, 44, $1-20$.

Gupta, Sanjay and Mary A. Hofmann. (2003) "The Effect of State Income Tax Apportionment and Tax Incentives on New Capital Expenditures," Journal of the American Taxation Association, 25, 1-25.

Head, Keith C., John Reis, and Deborah Swenson. (1999) "Attracting Foreign Manufacturing: Investment Promotion and Agglomeration," Regional Science and Urban Economics, 29, $197-218$.

Hekman, John S. (1982) "Survey of Location Decisions in the South," Economic Review, Federal Reserve Bank of Atlanta, (June), 6-19.

Henderson, Jason R. and Kevin T. McNamara. (1997) "Community Attributes Influencing Local Food Processing Growth in the U.S. Corn Belt," Canadian Journal of Agricultural Economics, 45, 235-250. . (2000) "The Location of Food Manufacturing Plant Investments in Corn Belt Counties," Journal of Agricultural and Resource Economics, 25, 680-697.

Holl, Adelheid. (2000) "Manufacturing Location and Impacts of Road Transport Infrastructure: Empirical Evidence from Spain,” Regional Science and Urban Economics, 34, 341-363.

Hoover, Edgar M. (1948) The Location of Economic Activity. McGraw-Hill, New York.

Hotelling, Harold. (1929) "Stability in Competition,” Economic Journal, 39, 47-57.

Isard, Walter. (1948) "Some Locational Factors in the Iron and Steel Industry since the Early Nineteenth Century," Journal of Political Economy, 56, 203-217.

Jacobs, Jane. (1969) The Economy of Cities. Vintage: New York.

Jones, Lonnie L. and Michael D. Woods. (2002) "Economic Location Theory and Practice," unpublished paper, Texas A\&M University.

(C) Southern Regional Science Association 2011. 
Kieschnick, Michael D. (1981) Taxes and Growth: Business Incentives and Economic Development. Council of State Planning Agencies: Washington, D.C.

Klier, Thomas and Daniel P. McMillen. (2008) "Clustering of Auto Supplier Plants in the U.S.: Generalized Method of Moments, Spatial Logit for Large Samples," Journal of Business \& Economic Statistics, 26, 460-471.

Lambert, Dayton M., Megan I. Garret, and Kevin T. McNamara. (2006a) "An Application of Spatial Poisson Models to Manufacturing Investment Location Analysis," Journal of Agricultural and Applied Economics, 38, 105-121.

. (2006b) "Food Industry Investment Flows: Implications for Rural Development," Review of Regional Studies, 36, 140-162.

LeSage, James P. and R. Kelley Pace. (2009) Introduction to Spatial Econometrics. CRC Press, Taylor and Francis Group.

Levinson, Arik. (1996) "Environmental Regulations and Manufacturers' Location Choices: Evidence from the Census of Manufactures," Journal of Public Economics, 62, 5-29.

List, John A. (2001) "US County-Level Determinants of Inbound FDI: Evidence from a TwoStep Modified Count Data Model," International Journal of Industrial Organization, 19, 953-973.

Lösch, August. (1954) The Economics of Location. Yale University Press: New Haven, CT.

McCann, Philip. (2001) Urban and Regional Economics. Oxford University Press: Oxford, U.K..

McGranahan, David A. (2000) "The Geography of New Manufacturing Technology: Implications for the Nonmetropolitan South," Southern Rural Sociology, 15, 84-103.

McLaughlin, Glenn E. and Stefan Robock. (1949) Why Industry Moves South. NPA Committee of the South. Report No.3. Kingsport Press: New York.

Mueller, Eva and James N. Morgan. (1962) "Location Decisions of Manufacturers," American Economic Review, 52, 204-217.

Papke, Leslie E. (1987) "Subnational Taxation and Capital Mobility: Estimates of Tax-Price Elasticities," National Tax Journal, 40, 191-203. . (1991) "Interstate Business Tax Differentials and New Firm Location: Evidence from Panel Data," Journal of Public Economics, 45, 47-68.

Plaut, Thomas R. and Joseph E. Pluta. (1983) "Business Climate, Taxes and Expenditures, and State Industrial Growth in the United States," Southern Economic Journal, 50, 99-119.

Porter, Michael E. (1990) The Competitive Advantage of Nations. Free Press: New York.

Schalk, H.J. and G. Untiedt. (2000) "Regional Investment Incentives in Germany: Impacts on Factor Demand and Growth,” Annals of Regional Science, 34, 173-195.

Schmenner, Roger W., Joel C. Huber, and Randall L. Cook. (1987) “Geographic Differences and the Location of New Manufacturing Facilities," Journal of Urban Economics, 21, 83104. 
Smith, Eldon D., Brady J. Deaton, and David R. Kelch. (1978) "Location Determinants of Manufacturing Industry in Rural Areas," Southern Journal of Agricultural Economics, $10,23-32$.

von Thünen, Johann H.. (1826) Der Isolierte Staat in Bezeihung auf Landwirtschaft und Nationalökonomie. Hamburg.

U.S. Department of Commerce. (2004) "Manufacturing in America." Available in December 2010 at: http://www.ita.doc.gov/media/Publications/pdf/manuam0104final.pdf.

Wasylenko, Michael and Therese McGuire. (1985) "Jobs and Taxes: The Effects of Business Climate on States' Employment Growth Rates," National Tax Journal, 38, 497-511.

Weber, Alfred. (1929) Theory of the Location of Industries. Translated by C. Friedrich. University of Chicago Press: Chicago.

Wheat, Leonard. (1986) "The Determinants of 1963-77 Regional Manufacturing Growth: Why the South and West Grow," Journal of Regional Science, 26, 635-660.

Woodward, Douglas P. (1992) "Location Determinants of Japanese Manufacturing Start-Ups in the United States," Southern Economics Journal, 58, 690-708.

Woodward, Douglas P. and Norman Glickman. (1991) "Regional and Local Determinants of Foreign Firm Location in the United States," in Henry W. Herzog and Alan M. Schlottmann (eds.), Industry Location and Public Policy. University of Tennessee Press: Knoxville, TN, pp. 190-220. 